九州大学学術情報リポジトリ

Kyushu University Institutional Repository

\title{
Smart Control System of Solar Panels
}

\section{Nasser, Eman}

Higher Technological Institute

Mona Ahmed Younis

Higher Technological Institute

Nasser, Amal

Higher Technological Institute

https://doi.org/10.5109/4739241

出版情報: Proceedings of International Exchange and Innovation Conference on Engineering \& Sciences (IEICES). 7, pp. 315-322, 2021-10-21. 九州大学大学院総合理工学府 バージョン:

権利関係 : 


\title{
Smart Control System of Solar Panels

\author{
Eman Nasser ${ }^{1}$, Mona Ahmed Younis ${ }^{1 *}$, Amal Nasser ${ }^{1}$ \\ ${ }^{1}$ Higher Technological Institute \\ *Corresponding author email: mona.younis@hti.edu.eg
}

\begin{abstract}
This article discusses smart controlling of solar panels with three modification systems for solar panels system which can increase the efficiency of the system and the output of the system, these three modification systems are cleaning system, cooling system, auto tracking system. This project aims to compare the promising methods of automatic cooling, cleaning and tracking, with the hope of obtaining a suitable scope in the design, application and future development of automatic cooling, cleaning and tracking technologies in photovoltaic systems. The cooling system is carried out by using a copper tube serpentine shaped installed in the back of the solar panel, which in turn transfers heat from the panel body to the coolant (water) inside the tube. As for the cleaning system, it is done through the cleaning brush, which moves on all the surface of the panel. Finally, the automatic tracking system depends on two main components, the Light Dependent Resistor (LDR) sensor and the actuator to move the panel.
\end{abstract}

Keywords: PV systems; solar panel; light dependent resistor; mechanical design.

\section{INTRODUCTION}

PV systems, which converts amount of solar radiation directly into electrical energy and are considered a sustainable energy source, may be utilized for a wide range of applications, from small systems powering sensors or domestic flights to large systems delivering electrical power immediately into the grid. Despite its broad range of uses, the system's basic configuration is straightforward the Photovoltaic system, which contains a collection of PV modules totaling the system's needed power capacity, is at the core of the system. the remaining subsystems include power conditioning and energy storage systems, arrays installation and supp ort, Safety assurance, and system performance assessment.

Using semiconductors, photovoltaic (PV) systems convert sunlight into electricity. PV devices may power everything from calculators and traffic lights to huge commercial residential complexes.

The operating circumstances and technical design of the system influence the system's performance, which is primarily concerned with energy output in terms of quantity and time. The system's position, in turn, impacts the quantity of solar energy received, the ambient temperature, and the operating conditions. as well as other weather elements that have an impact on the system's effectiveness.

PV systems are classified into two types depending on if they are linked to the local electricity grid or not.

Grid-connected systems are typically constructed to always provide highest energy output and to assist in the fulfilment of electrical demands, either nearby to the system or via the electricity network.

The objective of the system in this scenario is to supply the correct quantity of power to the stated load. Standalone PV systems operate independently of the grid and are frequently used in areas where there is no power or where connection to the grid is problematic.

PV systems are made up of a variety of components. Cells, which are generally made of silicon, are arranged on a module, which will then be connected to produce the system size required. These cells create a small direct current of electricity when exposed to sunlight, and when used in a group, they may generate a significant quantity of electrical power with no moving parts, noise, or contaminants.
After that, the power is delivered to an inverter, which transforms direct current to alternating current, which we use in our homes.

Grid-connected or stand-alone, stationary or tracked, flat plate, or concentrator operation, photovoltaic systems may be constructed in a variety of ways.

The Egyptian government understands the importance of a renewable energy mix to fulfil increasing demand while simultaneously switching to a more environmentally friendly and varied electrical industry. The 2035 Integrated Renewable Strategy, which builds on previous programmers, emphasizes renewable energy. By 2022, Egypt wants to increase the amount of power generated from renewable sources to $20 \%$. and by 2035 to $42 \%$, By 2035, wind electricity will account for 14 percent, hydroelectric will contribute for $2 \%$, and solar will account for $25 \%$. The private sector is expected to provide most of this capacity.[1].

\subsection{PV Panels}

A PV module is a photovoltaic cell assembly that has been placed in a framework and is ready for installation.

Photovoltaic cells use solar as a source of energy to create direct current electricity.

A PV Panel is a group of PV modules, whereas an Array is a group of Panels. A photovoltaic system's arrays provide solar energy to electrical devices. Photovoltaic systems can be constructed in a variety of configurations, such as grid-connected or stand-alone, fixed or tracked, flat plate, or concentrator operation.

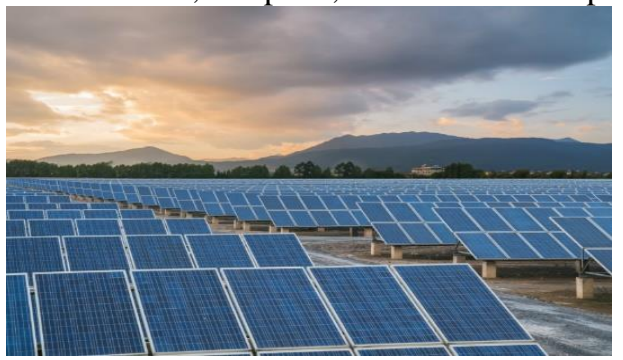

Fig. 1. PV Panels

\subsection{Operation method for PV system}

When the solar rays fall on the solar cell, the antireflective layer effectively retains the incident light by enhancing its transmission to the next layers. When the negative slice is exposed to sunlight, the energy of the photons is transferred to the electrons in the valence 
region to be able to move to the conduction area in the negative slice. On the other hand, the positive gaps move to the conduction area of the positive chip, resulting in a voltage difference between the two surfaces of the double link, and the two surfaces can be connected by an electrical conductor to obtain an electric current in an electrical circuit, where the electrons pass from the first link negative to the positive link in the electrical circuit, so we must convert light energy into electrical energy. [2:7]

\subsection{Structure of the Solar Panel}

Plenty of known solar panel producers are 'vertically integrated,' meaning that they supply and manufacture all the major components, including all the silicon ingots and wafers required to produce solar PV cells. Many solar panel producers, on the other hand, build solar panels with elements supplied from other sources, and as cells, polymer back sheets, and encapsulating EVA material. While these companies can be more careful about the components they use, as they do not need to monitor their product quality, they should make sure they select the best suppliers available.

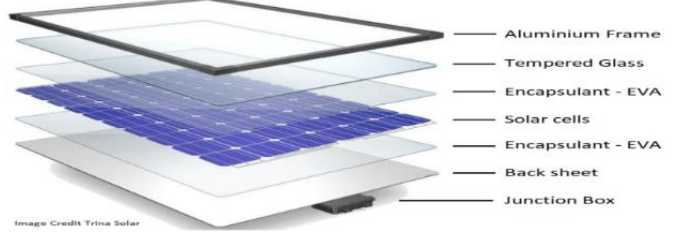

Fig. 1 Structure of the Solar Panel

\subsection{Classification of Photovoltaic (PV) Solar cell}

Every photovoltaic (PV) cell is made up of two or maybe more thin layers of semi-conductive material, most commonly silicone. When a semiconductor is exposed to sunlight, electrical charges are generated, which may be removed via metal contacts as direct current. Because a single cell's electrical output is limited, many cells are connected to form a line that generates direct current.

\subsubsection{Monocrystalline silicon PV panels}

Cells constructed from a single cylindrical silicon crystal are used to make these. This is the most efficient photovoltaic technology, turning around $17 \%$ of solar energy into electricity. The production method for monocrystalline silicone is complicated, resulting in somewhat higher costs than comparable technologies.

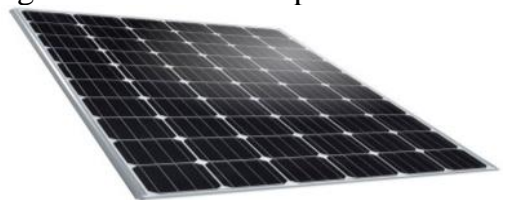

Fig. 2. Monocrystalline PV panel [5]

\subsubsection{Polycrystalline silicon $P V$ panels}

Regularly recognized as multi-crystalline cells, Polycrystalline silicon cells are produced from silicon ingots that have been melted and crystallized. After that, the flakes are sawed into ultra-thin wafers and reassembled into complete cells. Because of the easier manufacturing technique, they are generally less expensive to produce than monocrystalline cells, albeit they are slightly less efficient, with approximate efficiencies of around $13 \%-16$ percent $\%$.

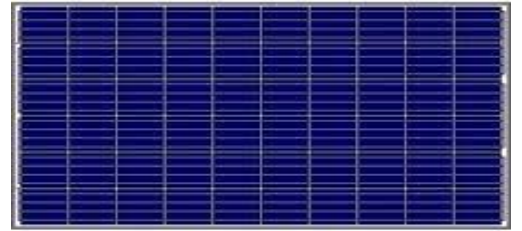

Fig. 3. Polycrystalline PV panel

\subsubsection{Thick-film silicon $P V$ panels}

This is a variation of multi-crystalline technology in which silicon is continuously deposited onto a base material, resulting in a fine-grained, dazzling look.

Before being combined into a metal framed module, thick-film silicon PV panels, like most of the other crystalline PV, are generally coated in a transparent insulating polymer with a tempered glass cover.

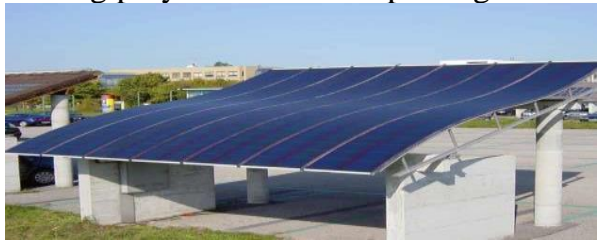

Fig. 4. Thick-film PV panel

\subsection{Types of Solar Panel:}

Solar power is a renewable energy technology that converts sunlight into electricity using photovoltaic modules. The electricity generated can be stored or utilised immediately, or it can be fed back into the grid or used off-grid.

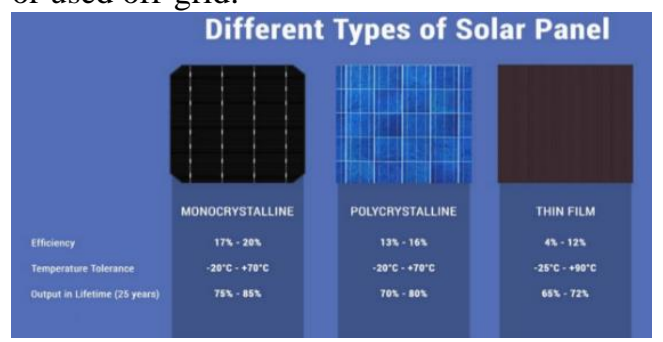

Fig. 5. Different types of solar panel

\subsubsection{On grid system}

They are solar energy stations that generate electricity and pump it into the public electricity network, and the sizes of these stations range from counting a kilowatt installed on the roofs of houses and up to several thousand kilowatts that are built on large areas of land and require permits and licenses from the electricity company to obtain approval to be installed and connected to the network.

If a special solar power station is constructed in a building, and it is connected to the network, the owner of the station consumes what he needs from the production of the solar station during the day, and what is more than his need is automatically pumped into the distribution network.

During the night, the electrical loads of this subscriber are fed with the electricity coming from the electricity company, and the accounting is done on the basis of the difference between what the solar plant produced and what was consumed by the network and this system is called net metering. 


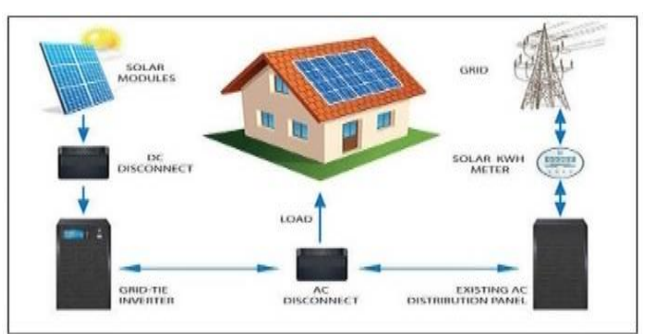

Fig. 6 . On grid system [8]

1.5.2 Off grid system

An off-grid system requires battery storage because it is not connected to the power grid.

Off-grid solar systems should be built properly to provide enough electricity all year and have enough battery capability to satisfy the demands of the residence, even when sunshine is scarce in the middle of winter. Off-grid systems are substantially more expensive than on-grid systems due to the high cost of batteries and offgrid inverters. They are generally only necessary in more distant, off-the-grid places for this reason.

However, as battery prices fall, a new market for offgrid solar battery solutions is emerging, even in cities.

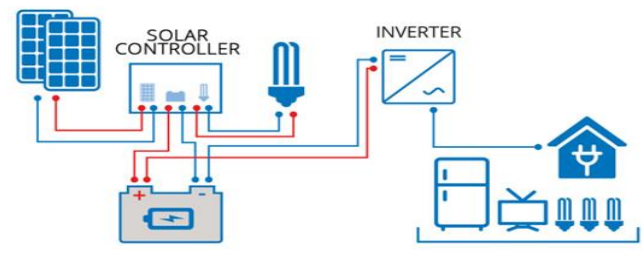

Fig. 7 . Off grid system [7]

\subsubsection{Hybrid PV system}

Modern hybrid systems combine solar and battery storage into a handheld device and come in a wide range of forms and sizes.

Because battery storage is becoming more affordable, systems that are already linked to the power grid can start to profit from it. This involves the capacity to store and utilize solar energy generated throughout the day. When the stored energy expires away, the grid takes over as a backup, offering customers the perfect combination. Offpeak power can also be used to charge the batteries in hybrid systems (usually after midnight to 6am).

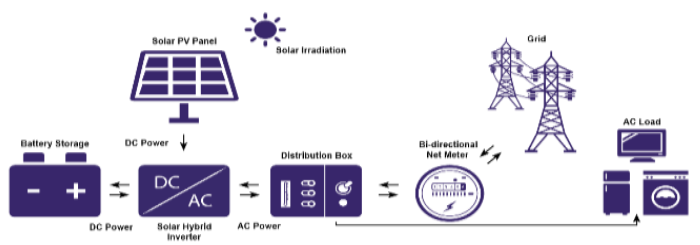

Fig. 8 . Hybrid PV system [8]

\subsection{Cleaning system}

When solar plants are unclean, their performance suffers. Under the same conditions, an unclean panel will produce $10 \%$ less than a fresh panel, depending on the quantity of dirt. Dirt comes in a variety of shapes and sizes. Pollution, accumulated dust, bird droppings, oil, or any other airborne particles that get stuck on the solar panels. Dirty parts of the panel also get hotter faster than other parts, which creates hotspots. These hotspots can increase the rate at which solar panels deteriorate. Solar panels operate by allowing the natural light from the sun to 'enter' its solar cells. The more natural light that hits the panel, the more energy the panel will generate. Below are good reasons why it is important to have clean solar panels. [3].

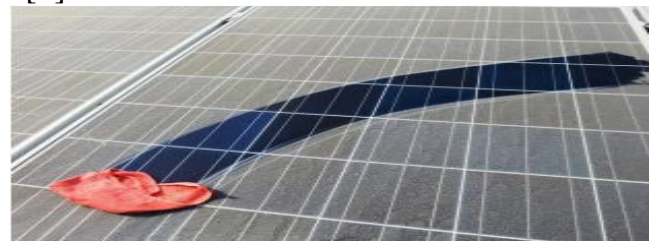

Fig. 10. Dust contaminated solar panel [3]

Hard shading and soft shading are the two forms of soil shading that may be found on PV modules. When some materials, such as smog, exist in the air, soft shading occurs, but hard shading occurs when a particle, such as accumulated dust, covers the sunlight. The current of the PV module is affected by soft shadowing, but the voltage remains constant.

Whether some or all a PV module's cells are shaded determines its performance when subjected to strong shadowing. If the unshaded cells receive some solar irradiation, the voltage generated by the PV module will decline if certain cells are shaded.

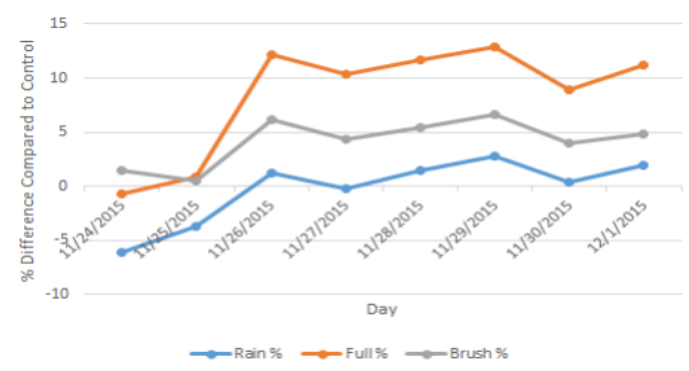

Fig. 11. Improvement in solar energy generation after cleaning [3]

Is it possible to get rid of the droppings? Solar panels are exposed to the possibility of bird droppings due to their placement. And, contrary to popular belief, rain does not wipe away the droppings. This reduces the quantity of light reaching the solar cells, lowering the overall energy generating yield. Furthermore, many solar panel manufacturers claim that the accumulation of these droppings will impair the panel's capacity to achieve anticipated performance.

To Avoid Dirt and Dust from Collecting Natural factors such as dust and grime can obscure a solar panel's surface, reducing its optimal efficiency. If solar panels are not washed on a regular basis, they will not operate at the level you expect, reducing your returns on investment and energy savings. Additionally, dust or other particles that have been placed on solar cells for a long time can affect the aluminum strip of the solar panel plate, so we avoid this damage with this system, and the solar panel reliability is expanded.

And to Enhance the Total Energy Efficiency The efficiency increase of the cleaned solar panels regularly are significant. Studies show that significant increases in the site's solar efficiency, for example, rise by $10-30 \%$ when they are preserved accurately using traditional cleaning facilities. users, who we frequently wash solar panels, have a $25 \%$ better performance associated with similar users who do not use it.

This conclusion is established by the World Academy of Science, Engineering \& Technology who say "a drop in the efficiency of a solar PV panel is not desired. One of 
the contributing factors in the drop of efficiency in solar PV panels is the accumulated dust on the solar panel. In practice, dust must be removed from the surface of solar PV panels in order to ensure highest performance." finally, if you need your panels to operate and keep going, maintain them clean.

\subsubsection{Why should you use clean solar panels?}

Dust particles in the air, sticky tree and plant drain, smoke, and bird droppings are just a few of the things that might cause debris to accumulate on your panels. As a result of the accumulation, sunlight will not reach the cells. This leads to poor system performance, efficiency loss, and a loss of financial return for solar energy owners and investors.

Cleaning your modules on a regular basis ensures optimal output, preserves your warranty, saves you money, extends the life of your investment, and prevents permanent stains.

\subsubsection{Technologies for panel cleaning:}

Cleaning solar panels is one of the vital and costeffectively critical problems to solve for both current and emergent technologies. Now, most solar panel systems depend on one of these:

Rainfall and wind speed: They are free but erratic, and rain is unusual in dry places. So, the consistency cleaning technique is difficult when stain is severe and rainfall is not sufficient, likewise in amount or in concentration, to clean the soil. Then severe drops in performance have been observed in several cases after a light rainfall. Wind can also reduce or remove soiling to a certain level, but there is a demand of water to wash the surface for optimal power generation.

Manual cleaning: Manual employment is used to brush the soil from the surface, brushes with special bridles are constructed to prevent scraping of the units. Some brushes are also linked directly to a water source to carry out the cleaning and brushing simultaneously. Employment cost, work safety, cleansing efficiency and quantity are very difficult.

Robots: technology is exploited to operate the washing task and a storage capacity for water supply. Regular washing cycles are advised to reduce effect of dust, weekly washing during dry seasons and daily cleaning advised for severe dust growth.

\subsection{Cooling system}

Temperature's Impact on Solar Panels When the panel temperature rises above $25{ }^{\circ} \mathrm{C}$, the open-circuit voltage drops dramatically, while the short-circuit current increases just little. The temperature coefficient is used to describe the influence of temperature on photovoltaic performance. As a result, as the temperature rises, the power output decreases. The temperature coefficient percentage reflects a change in production when the temperature rises or decreases above or below 25 degrees Celsius. As a result, it's critical to remove heat from the PV with proper cooling mechanisms in order to mitigate the detrimental effects of cell temperature and keep the operating temperature within the manufacturer's specified range.

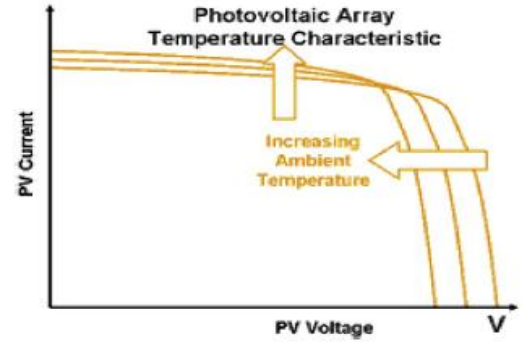

Fig. 12. characteristics of a solar P.V with the effect of temperature [4]

\subsection{Tracking system}

To accomplish dynamic motion control utilizing control automation architecture, circuit boards, and hardware, renewable energy control automation systems require automated solar tracking software and solar position algorithms.

In automated solar tracker applications, on-axis sun tracking systems, such as altitude-azimuth dual axis or multi-axis solar tracking system, use a sun tracking techniques or ray tracing sensors or software to ensure the sun's passage through the sky is traced with high precision, all the way through the summer solstice, and winter solstice. A sun position calculator with high precision, known as a Winter solstice and solar equinox

A software programmer routine also is used to align the solar tracker with the sun and is a critical feature of the model and mechanism of an automated solar tracking system.
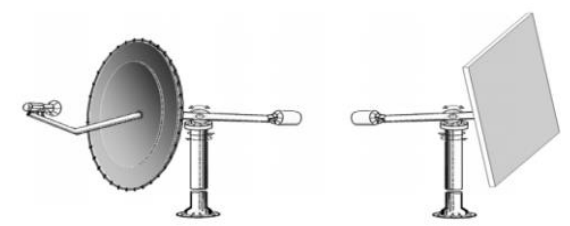

Fig. 13 Tracking system [4]

\section{EXPERIMENTAL WORK:}

\subsection{PV Solar System Component (Test Rig):}

PV array, solar charge controller, inverter, watt hour meter, auxiliary sources, and loads are the primary components of a solar PV system.

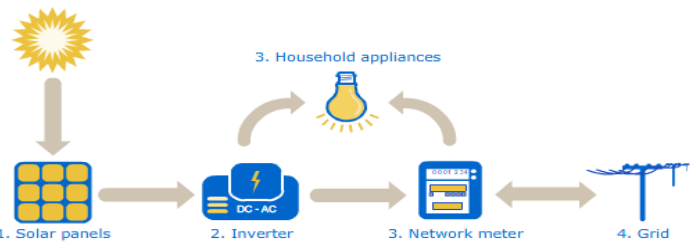

Fig. 9 . Major PV Solar System Component Figure 15 shows the new PV solar system component design

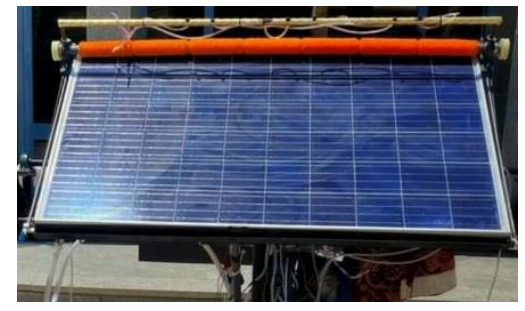

Fig. 15 test rig

2.1.1. Polycrystalline silicon $P V$ panel

A polycrystalline silicon PV panel is used Figure 16 


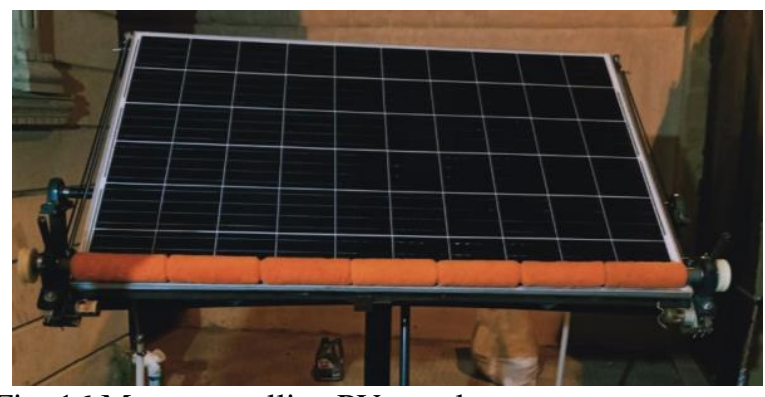

Fig. 16 Monocrystalline PV panel

2.1.2 Charge controller for solar panels

Regulates the voltage and current going to the battery from the PV panels, preventing battery overcharging and extending battery life.

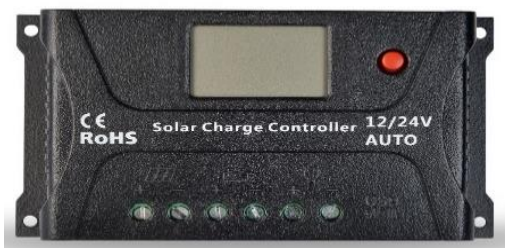

Fig.17. Solar charge controller

\subsubsection{Metal chassis}

Metal structure holding the panel on the upper frame.

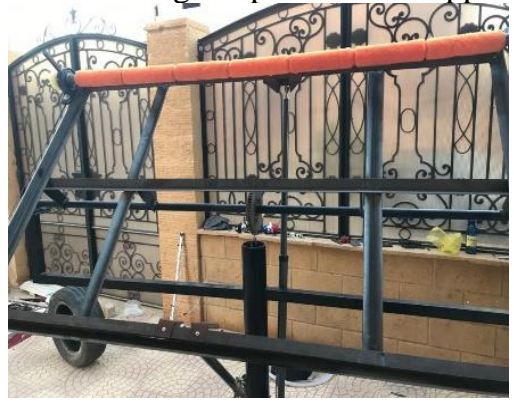

Fig. 18. Main structure

\subsubsection{Water pump}

DC Water pump (750GPH $-12 \mathrm{~V})$ used for water circulation on the cooling system.

Fig.19. Water pump

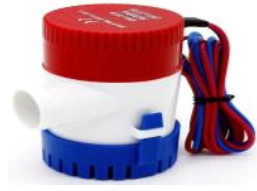

\subsubsection{Linear actuator}

An actuator for moving the solar panel and consider the main part of Auto tracking system.

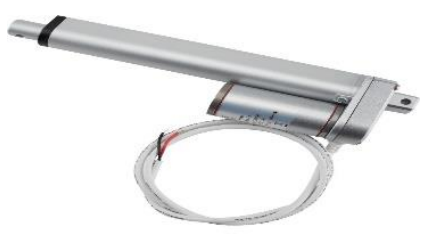

Fig. 20. Linear Actuator

\subsubsection{Arduino}

Arduino MEGA which plays the main role of controlling processes.

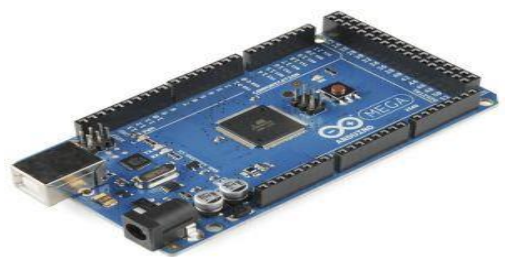

\subsubsection{Relay module}

An electronic circuit that switches the polarity of a voltage applied to a load.

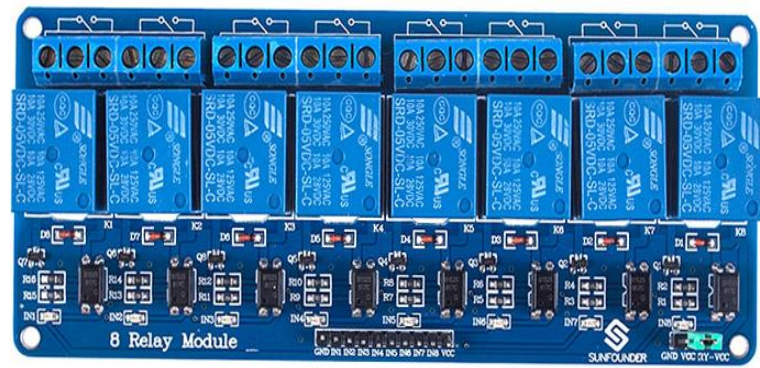

Fig. 22. Relay module

\subsubsection{Sensors}

\section{a. LDR Sensors}

Light dependent resistors (LDRs) are light-sensitive components that are commonly used to detect the amount of light, as well as to measure the intensity of light.

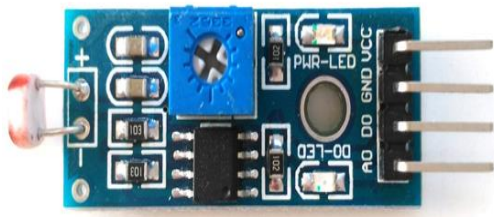

Fig. 23. LDR Sensor

\section{b. Temperature sensors}

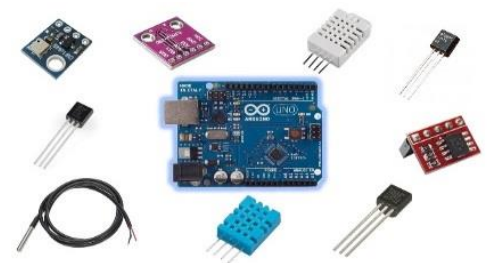

Fig. 24. Temperature Sensor

\subsubsection{Battery}

Two batteries (12 volts) are used as the power source and storage.

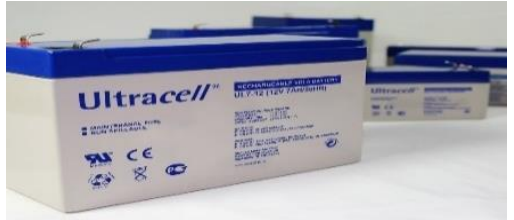

Fig. 25. Battery

\subsubsection{Electrical wires and switches}

It is used to control the closing and opening of the circuit as needed.

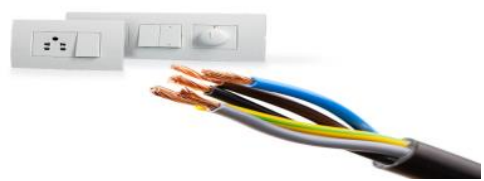

Fig. 26. Electrical wires and switches

\subsubsection{Cleaning brush}

It is used to cleaning the surface of the panel.

Fig. 21. Arduino 


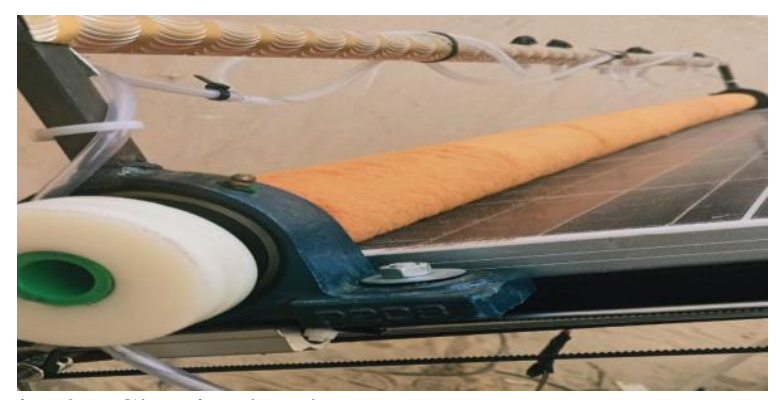

Fig. 27. Cleaning brush

\subsubsection{Cooling serpentine tube}

$15 \mathrm{~m}$ copper tube serpentine shaped facing behind the panel.
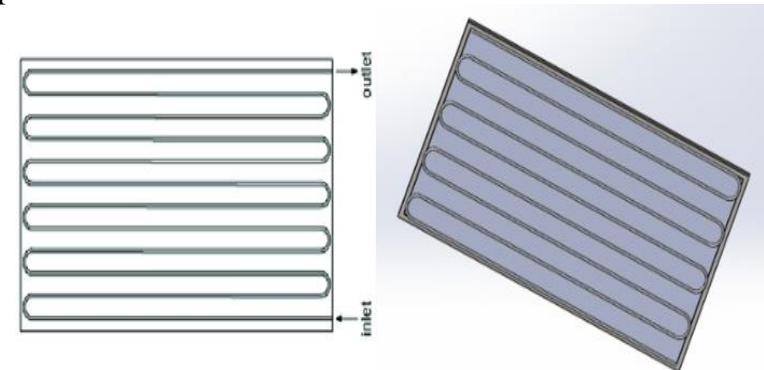

Fig. 28. Cooling serpentine tube

2.1.13 Mounted bearing

It is used to connect the shaft (which mounted to the plate) to the chassis.

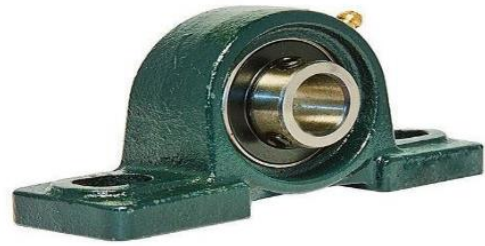

Fig. 29. Mounted bearing

\subsubsection{Linear rail}

Used to move the cleaning brush over the surface of the plate.

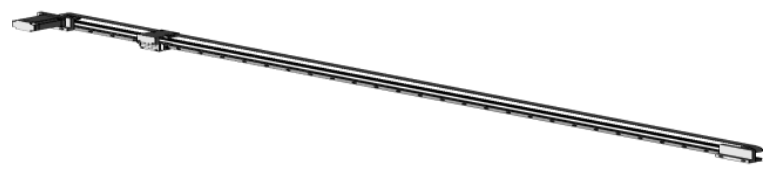

Fig.30. Linear rail

\section{Results and discussion:}

The objective of this project was to compare promising methods of automatic cooling, cleaning and tracking, with the hope of obtaining a suitable scope in the design, application and future development of automatic cooling, cleaning and tracking technologies in photovoltaic systems.

Tables 1,2,3 and 4 shows the obtained power, and temperature for four days. The maximum power obtained at $12 \mathrm{AM}$

Table 1. Day One

\begin{tabular}{|c|c|c|c|c|}
\hline Time & Electric current & Voltage & Power & Temperature \\
Day 1 & \multicolumn{4}{|c|}{ Fixed } \\
6:00 AM & $6.9 \mathrm{~A}$ & $30.1 \mathrm{~V}$ & $207.69 \mathrm{~W}$ & $26 \mathrm{C}$ \\
7:00 AM & $7.23 \mathrm{~A}$ & $30.2 \mathrm{~V}$ & $218.34 \mathrm{~W}$ & $26.4 \mathrm{C}$ \\
8:00 AM & $7.5 \mathrm{~A}$ & $30.3 \mathrm{~V}$ & $227.25 \mathrm{~W}$ & $27 \mathrm{C}$ \\
9:00 AM & $7.8 \mathrm{~A}$ & $30.6 \mathrm{~V}$ & $238.68 \mathrm{~W}$ & $27.6 \mathrm{C}$ \\
10:00 AM & $8.2 \mathrm{~A}$ & $30.8 \mathrm{~V}$ & $252.56 \mathrm{~W}$ & $28.6 \mathrm{C}$ \\
11:00 AM & $8.39 \mathrm{~A}$ & $31.2 \mathrm{~V}$ & $261.768 \mathrm{~W}$ & $29 \mathrm{C}$ \\
12:00 AM & $8.45 \mathrm{~A}$ & $31.4 \mathrm{~V}$ & $265.33 \mathrm{~W}$ & $31 \mathrm{C}$ \\
1:00 PM & $8.41 \mathrm{~A}$ & $31.4 \mathrm{~V}$ & $264.07 \mathrm{~W}$ & $32 \mathrm{C}$ \\
2:00 PM & $8.37 \mathrm{~A}$ & $31.1 \mathrm{~V}$ & $260.31 \mathrm{~W}$ & $30.4 \mathrm{C}$ \\
3:00 PM & $8.26 \mathrm{~A}$ & $30.9 \mathrm{~V}$ & $255.23 \mathrm{~W}$ & $30.2 \mathrm{C}$ \\
4:00 PM & $8.11 \mathrm{~A}$ & $30.7 \mathrm{~V}$ & $248.9 \mathrm{~W}$ & $29.6 \mathrm{C}$ \\
5:00 PM & $7.87 \mathrm{~A}$ & $30.5 \mathrm{~V}$ & $240.035 \mathrm{~W}$ & $29.2 \mathrm{C}$ \\
6:00 PM & $7.3 \mathrm{~A}$ & $30.3 \mathrm{~V}$ & $219.7 \mathrm{~W}$ & $29 \mathrm{C}$ \\
\end{tabular}

Day 1

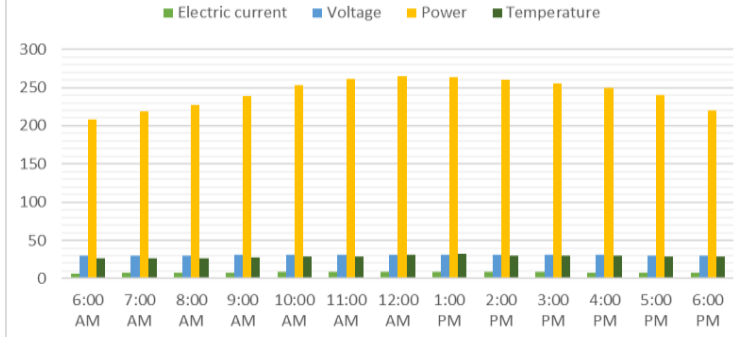

Fig. 31. day one

Table 2. day two

\begin{tabular}{|c|c|c|c|c|}
\hline Time & Electric current & Voltage & Power & Temperature \\
\hline Day 2 & \multicolumn{4}{|c|}{ Tracking } \\
\hline 6:00 AM & $7.15 \mathrm{~A}$ & $30.1 \mathrm{~V}$ & $215.22 \mathrm{~W}$ & $28 \mathrm{C}$ \\
7:00 AM & $7.21 \mathrm{~A}$ & $30.3 \mathrm{~V}$ & $218.5 \mathrm{~W}$ & $28.6 \mathrm{C}$ \\
8:00 AM & $7.6 \mathrm{~A}$ & $30.7 \mathrm{~V}$ & $233.32 \mathrm{~W}$ & $29.4 \mathrm{C}$ \\
9:00 AM & $7.78 \mathrm{~A}$ & $30.76 \mathrm{~V}$ & $239.31 \mathrm{~W}$ & $30 \mathrm{C}$ \\
10:00 AM & $7.92 \mathrm{~A}$ & $31.11 \mathrm{~V}$ & $246.4 \mathrm{~W}$ & $31.5 \mathrm{C}$ \\
11:00 AM & $8.32 \mathrm{~A}$ & $31.2 \mathrm{~V}$ & $259.6 \mathrm{~W}$ & $32.6 \mathrm{C}$ \\
12:00 AM & $8.47 \mathrm{~A}$ & $31.6 \mathrm{~V}$ & $267.7 \mathrm{~W}$ & $34.6 \mathrm{C}$ \\
1:00 PM & $8.43 \mathrm{~A}$ & $31.45 \mathrm{~V}$ & $265.12 \mathrm{~W}$ & $34.2 \mathrm{C}$ \\
2:00 PM & $8.26 \mathrm{~A}$ & $31.2 \mathrm{~V}$ & $257.7 \mathrm{~W}$ & $33.9 \mathrm{C}$ \\
3:00 PM & $7.96 \mathrm{~A}$ & $31.09 \mathrm{~V}$ & $247.5 \mathrm{~W}$ & $33.5 \mathrm{C}$ \\
4:00 PM & $7.84 \mathrm{~A}$ & $30.97 \mathrm{~V}$ & $242.8 \mathrm{~W}$ & $33 \mathrm{C}$ \\
5:00 PM & $7.63 \mathrm{~A}$ & $30.67 \mathrm{~V}$ & $234.01 \mathrm{~W}$ & $33 \mathrm{C}$ \\
6:00 PM & $7.35 \mathrm{~A}$ & $30.2 \mathrm{~V}$ & $221.97 \mathrm{~W}$ & $31.8 \mathrm{C}$ \\
\hline
\end{tabular}

Day 2

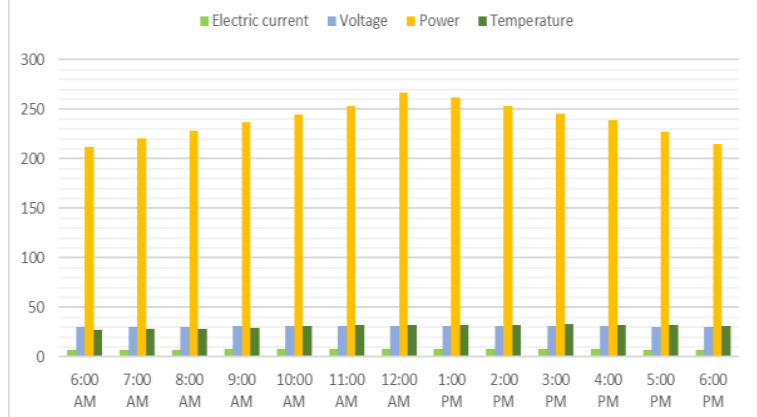

Fig. 32. day Two

Table 3. Day Three

\begin{tabular}{|c|c|c|c|c|} 
Time & Electric current & Voltage & Power & Temperature \\
Day 3 & \multicolumn{4}{|c|}{ Cooling } \\
6:00 AM & $7.02 \mathrm{~A}$ & $30.2 \mathrm{~V}$ & $212 \mathrm{~W}$ & $27 \mathrm{C}$ \\
7:00 AM & $7.25 \mathrm{~A}$ & $30.43 \mathrm{~V}$ & $220.62 \mathrm{~W}$ & $28 \mathrm{C}$ \\
8:00 AM & $7.43 \mathrm{~A}$ & $30.68 \mathrm{~V}$ & $227.95 \mathrm{~W}$ & $28.5 \mathrm{C}$ \\
9:00 AM & $7.68 \mathrm{~A}$ & $30.79 \mathrm{~V}$ & $236.5 \mathrm{~W}$ & $29.7 \mathrm{C}$ \\
10:00 AM & $7.91 \mathrm{~A}$ & $30.97 \mathrm{~V}$ & $244.97 \mathrm{~W}$ & $31.2 \mathrm{C}$ \\
11:00 AM & $8.12 \mathrm{~A}$ & $31.23 \mathrm{~V}$ & $253.6 \mathrm{~W}$ & $31.9 \mathrm{C}$ \\
12:00 AM & $8.49 \mathrm{~A}$ & $31.42 \mathrm{~V}$ & $266.75 \mathrm{~W}$ & $32.3 \mathrm{C}$ \\
1:00 PM & $8.36 \mathrm{~A}$ & $31.3 \mathrm{~V}$ & $261.7 \mathrm{~W}$ & $32.6 \mathrm{C}$ \\
2:00 PM & $8.13 \mathrm{~A}$ & $31.11 \mathrm{~V}$ & $252.92 \mathrm{~W}$ & $32.6 \mathrm{C}$ \\
3:00 PM & $7.94 \mathrm{~A}$ & $30.92 \mathrm{~V}$ & $245.5 \mathrm{~W}$ & $32.7 \mathrm{C}$ \\
4:00 PM & $7.76 \mathrm{~A}$ & $30.74 \mathrm{~V}$ & $238.54 \mathrm{~W}$ & $32.4 \mathrm{C}$ \\
5:00 PM & $7.45 \mathrm{~A}$ & $30.56 \mathrm{~V}$ & $227.67 \mathrm{~W}$ & $32.1 \mathrm{C}$ \\
6:00 PM & $7.08 \mathrm{~A}$ & $30.31 \mathrm{~V}$ & $214.6 \mathrm{~W}$ & $31.6 \mathrm{C}$ \\
& & & &
\end{tabular}




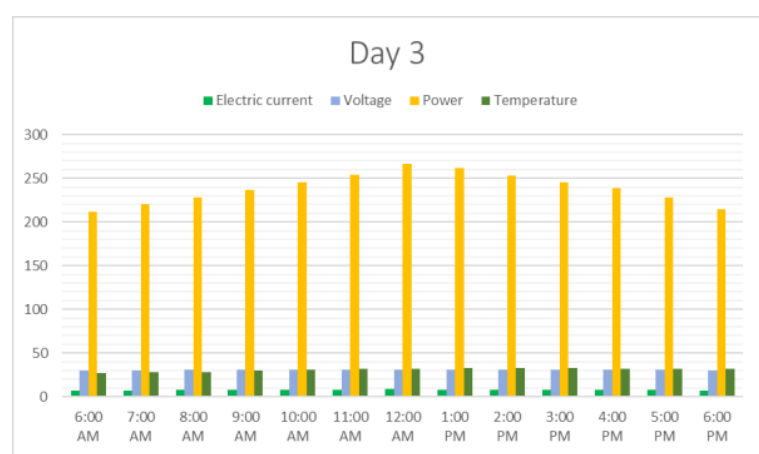

Fig. 33. Day three

Table 4. day four

\begin{tabular}{|c|c|c|c|c|} 
Time & Electric current & Voltage & Power & Temperature \\
Day 4 & \multicolumn{3}{|c|}{ Tracking and Cooling } \\
6:00 AM & $7.1 \mathrm{~A}$ & $30.2 \mathrm{~V}$ & $214.42 \mathrm{~W}$ & $29 \mathrm{C}$ \\
7:00 AM & $7.28 \mathrm{~A}$ & $30.37 \mathrm{~V}$ & $221.1 \mathrm{~W}$ & $29.2 \mathrm{C}$ \\
8:00 AM & $7.34 \mathrm{~A}$ & $30.67 \mathrm{~V}$ & $225.12 \mathrm{~W}$ & $29.6 \mathrm{C}$ \\
9:00 AM & $7.86 \mathrm{~A}$ & $30.81 \mathrm{~V}$ & $242.2 \mathrm{~W}$ & $30.3 \mathrm{C}$ \\
10:00 AM & $8.17 \mathrm{~A}$ & $30.95 \mathrm{~V}$ & $252,86 \mathrm{~W}$ & $30.4 \mathrm{C}$ \\
11:00 AM & $8.38 \mathrm{~A}$ & $31.32 \mathrm{~V}$ & $262,5 \mathrm{~W}$ & $30.8 \mathrm{C}$ \\
12:00 AM & $8.55 \mathrm{~A}$ & $31.49 \mathrm{~V}$ & $269.23 \mathrm{~W}$ & $31.4 \mathrm{C}$ \\
1:00 PM & $8.42 \mathrm{~A}$ & $31.38 \mathrm{~V}$ & $264.21 \mathrm{~W}$ & $31.5 \mathrm{C}$ \\
2:00 PM & $8.23 \mathrm{~A}$ & $31.23 \mathrm{~V}$ & $257.02 \mathrm{~W}$ & $31.45 \mathrm{C}$ \\
3:00 PM & $8.1 \mathrm{~A}$ & $31.01 \mathrm{~V}$ & $251.2 \mathrm{~W}$ & $31.3 \mathrm{C}$ \\
4:00 PM & $7.92 \mathrm{~A}$ & $30.78 \mathrm{~V}$ & $243.7 \mathrm{~W}$ & $31.2 \mathrm{C}$ \\
5:00 PM & $7.74 \mathrm{~A}$ & $30.56 \mathrm{~V}$ & $236.53 \mathrm{~W}$ & $31.1 \mathrm{C}$ \\
6:00 PM & $7.26 \mathrm{~A}$ & $30.24 \mathrm{~V}$ & $219.5 \mathrm{~W}$ & $31 \mathrm{C}$ \\
& \multicolumn{4}{|c}{} \\
\end{tabular}

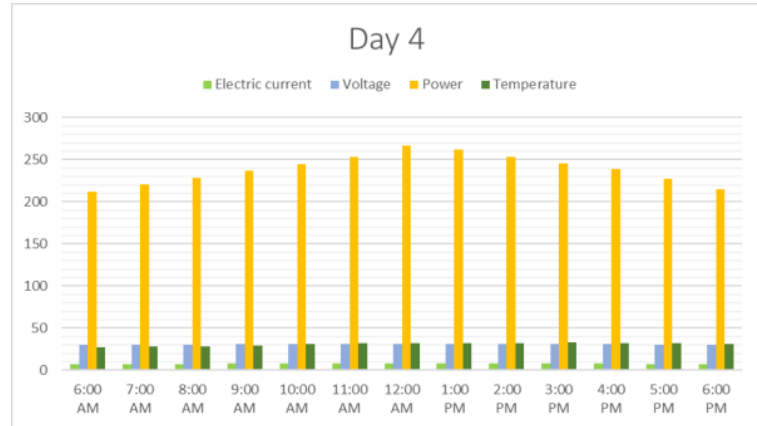

Fig. 34. day four

Figures 35 and 36 shows obtained power and current for four days

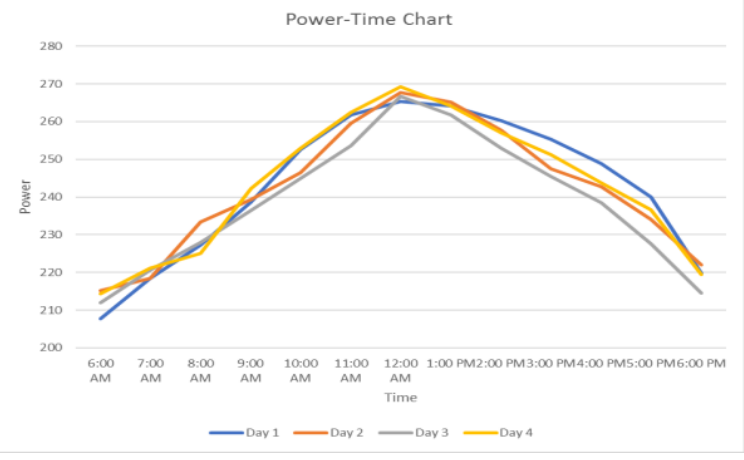

Fig. 35. power vs time for four days

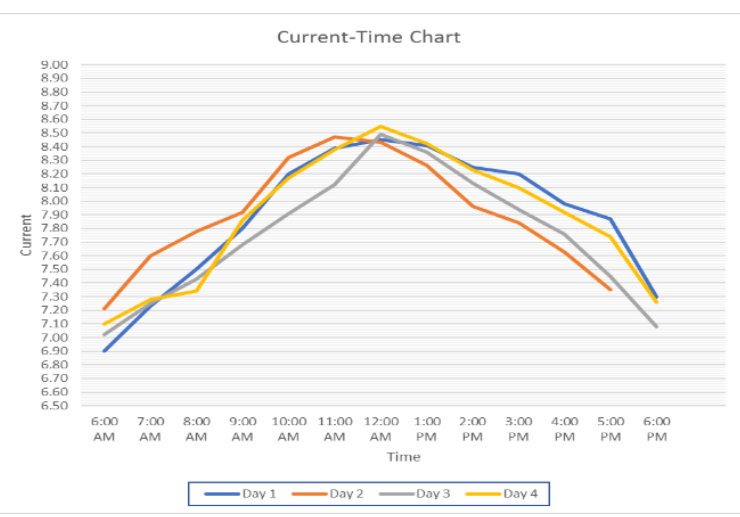

Fig.36. Current vs time for four days

\section{CONCLUSION}

- Although solar panels are normally self-cleaning, dust and other particles such as bird droppings can accumulate over time in particularly dry places or if panel tilt is limited, reducing the quantity of electricity generated by a module. Solar panels may need to be cleaned at this point.

- One of the participating considerations in the decline of efficiency in solar PV panels is the accrued dust on the solar panel.

- Cleansing and rainfall will increase panel output, while on average they will have a smaller amount of dirt on them.

- Automated solar tracking improves the solar panel efficiency by maintaining the solar panel aligned with the rotating sun.

- Solar tracking systems are used to keep solar panels and collectors aligned with the sun motion during the day. which increase the amount of solar energy collected by the solar energy collector, expanding the energy output of the heat/electricity created.

- Solar panels are typically tested at around 77 degrees Fahrenheit and are rated to work at peak efficiency between 59- and 95-degrees Fahrenheit.

- During the summer, though, solar panels can reach temperatures of $149^{\circ} \mathrm{F}$.

- When the surface temperature of your solar panels rises to this level, the efficiency of your panels may suffer. Solar panels don't work well when overheated. Now, many ways have found to make them allow them to cool themselves and increase their power output.

- Commonly, solar panels lose efficiency when their temperature increases to $77^{\circ} \mathrm{F}$. then, for every degree rise a solar panel loses effectiveness by the rate of its temperature coefficient.

- The output current of the solar panel increases exponentially as the temperature of the panel rises, whereas the voltage output decreases linearly.

- In fact, the voltage drop is so consistent that it may be used to precisely monitor temperature.

- As a result, heat can significantly impair the solar panel's ability to generate electricity.

\section{REFERENCES}

[1] B.V. Chikate, Y. Sadawarte, the factors affecting the performance of solar cell, Int. J. Comput. Appl. Sci. Technol. (2015).

[2] M.A. Bashir, H.M. Ali, M. Ali, S. Khalil, A.M. Siddiqui, Comparison of performance measurements of 
photovoltaic modules during winter months in Taxila, Pakistan, Int. J. Photoenergy (2014).

[3] B. Koteswararao, K. Radha, P. Vijay, N. Raja, Experimental analysis of solar panel efficiency with different modes of cooling 8 (2016).

[4] J. Siecker, A review of solar photovoltaic systems cooling technologies, Renew. Sustain. Energy Rev. (2017).

[5] M. Hasanuzzaman, Global advancement of cooling technologies for P.V. systems. a review, Sol. Energy (2016).

[6] D. Du, J. Darkwa, G. Kokogiannakis, Thermal management systems for photovoltaics (P.V.) installations. a critical review, Sol. Energy (2013).

[7] Ceylan, A.E. Gürel, H. Demircan, B. Aksu, Cooling of a photovoltaic module with temperature controlled solar collector, Energy Build. (2014) .

[8] M.A. Bashir, H.M. Ali, K.P. Amber, M.W. Bashir, A. Hassan, S. Imran, M. Sajid, Performance investigation of photovoltaic modules by back surface water cooling, Therm. Sci. (2016). 